\title{
$\bar{A}_{L-Q A \mathcal{D A}}{ }^{\mathrm{UR}} \mathrm{U}$ \\ PERADILAN dan HUKUM KELUARGA ISLAM
}

\section{Sertifikasi dan Labelisasi Produk Halal Perspektif Maslahat}

Certification and Labeling Halal Products of Maslahat Perspective

Musyfikah Ilyas

Dosen Fakultas Syariah dan Hukum UIN Alauddin Makassar

Email: musyfikah.ilyas@uin-alauddin.ac.id

\begin{tabular}{|c|c|}
\hline $\begin{array}{c}\text { Info } \\
\text { Artikel }\end{array}$ & Abstract \\
\hline $\begin{array}{l}\text { Diterima } \\
18 \\
\text { September } \\
2017\end{array}$ & $\begin{array}{l}\text { Sertifikasi dan labelisasi produk halal perspektif maslahat memberikan } \\
\text { perlindungan, jaminan, informasi tentang kehalalan produk yang } \\
\text { dikonsumsi dan digunakan masyarakat. Kebutuhan konsumen terhadap } \\
\text { sertifikasi dan labelisasi produk halal dikategorikan maslahat dharuriyyah } \\
\text { karena faktor kemajuan pengetahuan dan teknologi menyebabkan } \\
\text { semakin rumitnya menentukan produk halal atau haram, sehingga } \\
\text { dibutuhkan penetapan sertifikasi dan labelisasi produk halal. Maslahat } \\
\text { dharuriyah dapat dilaksanakan secara bertahap dan berkesinambungan. }\end{array}$ \\
\hline $\begin{array}{l}\text { Revisi I } \\
16 \\
\text { Oktober }\end{array}$ & Kata Kunci : Sertifikasi, Labelisasi, Halal, Maslahat. \\
\hline $\begin{array}{l}\text { Revisi II } \\
12 \\
\text { Nopember } \\
2017\end{array}$ & $\begin{array}{l}\text { Certification and labeling halal products of maslahat perspective provides } \\
\text { protection, guarantees, information about halal products consumed and } \\
\text { used by society. Consumer demand of halal certification and product } \\
\text { labeling is categorized as maslahat dharuriyyah because of the } \\
\text { improvement of knowledge and technology led to the growing } \\
\text { complexity to determine the lawful or unlawful of the product, so that } \\
\text { the establishment of certification and labeling of halal products is truly } \\
\text { needed. Maslahat dharuriyah can be implemented gradually and } \\
\text { continuously. }\end{array}$ \\
\hline $\begin{array}{l}\text { Disetujui } \\
04 \\
\text { Desember } \\
2017\end{array}$ & Keywords : Certification, Labeling, Halal, Maslahat \\
\hline
\end{tabular}


Musyfikah Ilyas

\section{PENDAHULUAN}

Pembangunan dan perkembangan perekonomian pada umumnya dan khususnya di bidang perindustrian dan perdagangan nasional telah menghasilkan berbagai variasi barang dan atau jasa yang dapat dikonsumsi. Di samping itu, globalisasi dan perdagangan bebas yang didukung oleh kemajuan teknologi telekomunikasi dan informatika telah memperluas ruang gerak arus transaksi barang dan atau jasa melintasi batas-batas wilayah suatu negara, sehingga barang dan atau jasa ditawarkan bervariasi baik produksi luar negeri maupun produksi dalam negeri. Kondisi yang demikian pada satu pihak mempunyai manfaat bagi konsumen karena kebutuhan konsumen akan barang dan jasa yang diinginkan dapat terpenuhi serta semakin terbuka lebar kebebasan untuk memilih aneka jenis kualitas barang dan atau jasa sesuai dengan keinginan dan kemampuan konsumen. Di sisi lain, kondisi dan fenomena tersebut diatas dapat mengakibatkan kedudukan pelaku usaha dan konsumen menjadi tidak seimbang dan konsumen berada pada posisi yang lemah. Konsumen menjadi objek aktivitas bisnis untuk meraup keuntungan yang sebesar-besarnya oleh pelaku usaha melalui kiat promosi, cara penjualan serta penerapan perjanjian standar yang merugikan konsumen. ${ }^{1}$

Atas dasar kondisi sebagaimana dipaparkan diatas, perlu upaya pemberdayaan dan perlindungan konsumen dalam hal sertifikasi dan labelisasi produk halal yang pada dasarnya sangat terkait dengan hajat kehidupan orang banyak.

Pada dasarnya manusia dengan akal pikirannya dapat mengetahui jenis-jenis makanan yang layak untuk dirinya. Manusia dengan akalnya membuat aturan tentang wewenang, hak dan kewajiban antara sesamanya dalam memenuhi kebutuhannya. Akal pikiran manusia sesungguhnya dapat mengetahui makanan apa yang pantas dan baik untuk dirinya, baik secara kepatutan, kesehatan, maupun norma sosial.

Dalam al-Quran, Allah memerintahkan manusia mengkonsumsi makanan dan minuman yang tidak hanya halal namun harus juga baik.

\footnotetext{
${ }^{1}$ M.Sadar, Moh.Taufik Makaroi, Habloel Mawardi, Hukum Perlindungan Konsumen di Indonesia (Cet.I; Jakarta: Akademia, 2012), h. 2
} 
Q.S. al Maidah (5): 88

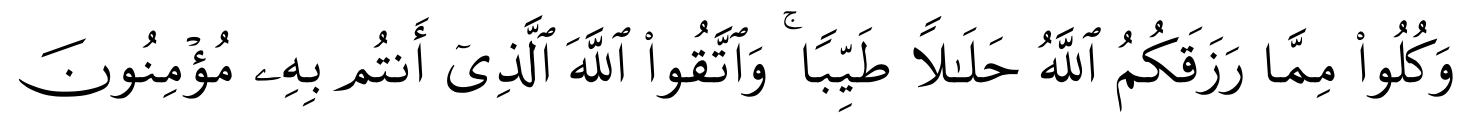

Terjemahan:

Dan makanlah makanan yang halal lagi baik dari apa yang Allah telah rezekikan kepadamu, dan bertakwalah kepada Allah yang kamu beriman kepada-Nya.

Pada ayat ini Allah memerintahkan kepada hambanya agar mereka makan rezeki yang halal dan baik, yang telah dikaruniakan kepada mereka. Halal di sini mengandung pengertian halal bendanya dan halal cara memperolehnya. Sedangkan baik adalah dari segi kemanfaatannya, yaitu yang mengandung manfaat dan maslahat bagi tubuh, mengandung gizi, vitamin, protein dan sebagainya. Makanan tidak baik selain tidak mengandung gizi, juga jika dikonsumsi akan merusak kesehatan. ${ }^{2}$

Ayat ini memerintahkan untuk memakan yang halal lagi baik. Maksud ayat tersebut tidak terbatas pengertiannya hanya pada makanan, tetapi juga produk-produk lainnya, seperti kosmetika, obat dan barang gunaan lainnya yang harus halal. Namun pada zaman sekarang, yang diikuti perkembangan teknologi proses pengolahan makanan minuman, kosmetika dan obat telah melibatkan proses yang kompleks dan mengandung aneka ragam bahan sehingga permasalahan makanan, minuman obat kosmetika dan barang gunaan halal menjadi tidak seimbang, penetapan kehalalan suatu produk halal tidaklah mudah.

Kemajuan ilmu pengetahuan dan teknologi di bidang pangan dewasa ini menyebabkan semakin rumitnya menentukan mana yang halal dan mana yang haram. Produk-produk pangan olahan semakin banyak beredar juga membutuhkan penetapan kehalalannnya, tidak hanya dari bahan bakunya tetapi juga mencakup penyediaan bahan, pengolahan, penyimpanan, pengemasan, pendistribusian, penjualan, dan penyajian produk. Oleh karena itu dibutuhkan pengetahuan yang cukup memadai tentang pedoman atau standar hukum Islam untuk mengetahui kehalalan dan keharaman suatu produk.

\footnotetext{
${ }^{2}$ Departemen Agama, Al-Qur'an dan Tafsirnya, Jilid 3 (Cet.III; Jakarta: Lembaga Percetakan alQur'an Departemen Agama, 2009), h. 6.
} 
Musyfikah Ilyas

Negara menjamin setiap pemeluk agama untuk beribadah dan menjalankan ajaran agamanya, terkhusus bagi umat Islam diperlukan adanya jaminan kehalalan terhadap semua produk makanan, minuman, obat, kosmetika dan barang gunaan yang diperdagangkan dan tentunya banyak dikonsumsi umat Islam. Jaminan halal tersebut bukan hanya dinyatakan oleh produsen, tetapi harus melalui suatu proses pemeriksaan dan assessment secara objektif oleh lembaga pemeriksa halal. ${ }^{3}$ Keterangan bahwa sistem produk telah dinyatakan halal adalah dengan pemberian sertifikasi halal sedangkan produk yang dihalalkan untuk konsumen diinformasikan status kehalalannya dengan tanda halal pada kemasan produknya.

Sertifikasi dan labelisasi halal haruslah memenuhi kaidah syariah yang ditetapkan dalam penetapan kehalalan suatu produk pangan, dalam hal ini akan berkaitan dengan kompetensi lembaga yang mengeluarkan sertifikat standar halal yang digunakan, personil yang terlibat dalam sertifikasi dan auditing, dan yang kalah pentingnya adalah mekanisme sertifikasi halal itu sendiri. Dengan demikian diperlukan adanya sesuatu standard sistem yang dapat menjamin kebenaran hasil sertifikasi halal.

Kasus besar salah satu produk penyedap rasa (MSG) dari PT. Ajinomoto Indonesia (dan PT. Ajinex Internasional) pernah mencuat di permukaan sangat meresahkan masyarakat dalam proses produksinya sejak bulan juni 1999 sampai akhir Nopember 2000 diketahui telah menggunakan bahan penolong berupa bactosoytone yang ternyata mengandung unsur babi. ${ }^{4}$ Produk penyedap rasa (MSG) dari PT. Ajinomoto Indonesia yang menggunakan bactosoytone dalam proses produksinya adalah haram. Belajar dari kasus tersebut maka Mejelis Ulama Indonesia (MUI) berusaha berperan untuk menentramkan umat Islam dalam masalah kehalalan produk pangan demgan cara mendirikan lembaga pengkajian pangan, obat-obatan dan kosmetika MUI (LPPOM MUI) untuk melakkan pengkajian produk halal.

Indonesia sebagai Negara yang mayoritas penduduknya muslim dan sebagai Negara berpenduduk beragama Islam terbesar di dunia sudah sepantasnya menempatkan masalah penyediaan produk yang halal pada posisi yang penting. Umat

\footnotetext{
${ }^{3}$ Departemen Agama, Pedoman Labelisasi Halal, Jakarta: Direktorat Jenderal Bimbingan Masyarakat Islam dan Penyelengaraan Haji, 2003. H. 5

${ }^{4}$ Departemen Agama, Himpunan Fatwa Majelis Ulama Indonesia (Jakarta: Direktorat Jenderal Bimbingan Masyarakat Islam dan Penyelenggaraan Haji, 2003), h. 350-357.
} 
Musyfikah Ilyas

Islam berhak untuk mendapatkan perindungan dan jaminan hukum atas kehalalan barang-barang yang dikonsumsi dan digunakannya, baik produk yang diproduksi di dalam negeri maupun yang dari luar.

Untuk menginformasikan kepada masyarakat bahwa produk yangdijual telah halal, pemerintah telah mengatur regulasi hukum yang berkaitan dengan undangundang nomor 7 tahun 1996 tentang pangan, Undang-undang Nomor 8 Tahun 1999 tentang perlindungan konsumen, Peraturan Pemerintah Nomor 69 Tahun 1999 tentang label dan iklan pangan dan Undang-undang nomor 33 Tahun 2014 tentang jaminan produk halal.

Regulasi aturan produk halal telah ada namun tidak dipungkiri masih belum memasyarakat secara luas, sehingga masyarakat masih bingung untuk mendapatkan produk yang benar-benar terjamin kehalalannya. Hal ini karena tidak sedikit produkproduk yang mencamtumkan tanda halal secara ilegal, pengolahan pangan dan non pangan, status kehalalan dari produk-produk yang berada di pasaran menjadi sangat rawan, disebabkan proses pengolahan menjadi sangat kompleks dan melibatkan banyak pihak serta pelaku usaha yang lain. Proses produksi di industri akan melibatkan berbagai ingredient, baik bahan baku, bahan tambahan dan bahan penolong, yang sering didatangkan dari supplier lain. Tidak sedikit ingredient yang digunakan diimpor dari Negara lain yang mayoritas penduduknya non muslim, yang memungkinkan bahannya berstatus syubhat atau bisa juga haram. Pegolahan makanan dalam produksinya menggunakan enzim, shortening, lemak hewani, bahan baku berbasis daging, flavor dan lain sebagainya. Bahan-bahan terebut sangat rawan dari kehalalan karena bisa saja mengadung bahan yang diharamkan. Oleh karena itu peran maslahat pada sertifikasi dan labelisasi produk halal membawa dampak yang sangat besar sehingga umat mendapatkan manfaat yang sangat besar dan menumbuh kembangkan kesadaran masyarakat untuk mengkonsumsi, menggunakan dan memanfaatkan produk halal dan selektif memilih produk yang sudah tersertifikasi dan berlabelisasi halal. Atas dasar ini akan dikaji tentang fungsi dan peranan maslahat dalam hukum Islam dengan melihat perubahan dan perkembangan situasi dan kondisi masyarakat tentang sertifikasi dan labelisasi produk halal. Dengan cara ini pula akan diketahui peluang maslahat sebagai pertimbangan dalam membangun hukum Islam di masa sekarang. 
Musyfikah Ilyas

Oleh karena itu akan dijelaskan tentang bagaimana sertifikasi dan labelisasi produk halal perspektif maslahat.

\section{PEMBAHASAN}

Kata halal berasal dari akar kata yang berarti "lepas" atau "tidak terikat". Sesuatu yang halal artinya sesuatu yang terlepas dari ikatan bahaya duniawi dan ukhrawi. Dalam bahasa hukum, kata halal berarti boleh. Kata ini mencakup segala sesuatu yang dibolehkan agama, baik dibolehkan itu bersifat sunnah, anjuran untuk dilakukan, atau makruh (anjuran untuk ditinggalkan), maupun mubah (netral/ bolehboleh saja).

Produk adalah barang dan/ atau jasa yag terkait dengan makanan, minuman, obat, kosmetik, produk kimiawi, produk kimiawi, produk biologi, produk rekayasa genetik, serta barang gunaan yang dipakai, digunakan atau dimanfaatkan oleh masyarakat. Produk halal merupakan produk yang telah dinyatakan halal sesuai dengan syariat Islam. Sertifikasi halal adalah pengakuan kehalalan suatu produk yang dikeluarkan oleh badan penyelenggara jaminan produk halal berdasarkan fatwa halal tertulis yan dikeluarkan majelis ulama. Labelisasi halal adalah tanda kehalalan suatu produk. ${ }^{5}$

Untuk menjamin setiap pemeluk agama untuk beribadah dan menjalankan ajaran agamanya, Negara berkewajiban memberikan perlindungan dan jaminan tentang kehalahan produk yang dikomsumsi dan digunakan masyarakat karena produk yang beredar di kalangan masyarakat belum semua terjamin kehalalannya. Kebutuhan konsumen terhadap produk yang beredar di masyarakat, terkadang membutuhkan produk yang mengadung unsur tertentu dan terkadang menghindari unsur tertentu pula. Ketidakmampuan konsumen untuk mengevaluasi apakah produk itu dijamin kehalalannya atau tidak sehingga dibutuhkan lembaga yang mempunyai kualifikasi untuk mengevaluasi hal tersebut. Lembaga itulah yang nantinya berhak untuk mensertifikasi suatu produk.

Pedoman dan terselenggaranya sertifikasi dan labelisasi produk halal, tentunya akan merujuk pada aturan perundangan nomor 33 tahun 2014 tentang jaminan produk halal yang selanjutnya disebut JPH mulai dari penyelenggaraan yang berasaskan

\footnotetext{
${ }^{5}$ Pasal 1 angka 2, 10, 11, Undang-undang No. 33 Tahun 2014 tentang Jaminan Produk Halal.
} 
perlindungan; keadilan; kepastian hukum; akuntabilitas dan transparansi; efektivitas dan efisiensi; serta profesionalitas.

Penyelenggaraan JPH bertujuan: a. memberikan kenyamanan, keamanan, keselamatan, dan kepastian ketersediaan Produk Halal bagi masyarakat dalam mengonsumsi dan menggunakan Produk; dan b. meningkatkan nilai tambah bagi Pelaku Usaha untuk memproduksi dan menjual Produk Halal. Hal ini dikarenakan produk yang masuk, beredar, dan diperdagangkan di wilayah Indonesia wajib bersertifikat halal. Frasa wajib pada Undang-undang tersebut memerlukan reinterpretasi jika dihubungkan dengan maslahat.

Untuk menjalankan Undang-undang tersebut akan dibentuk Badan Penyelenggara Jaminan Produk Halal yang disingkat dengan BPJPH yang berwenang: a. merumuskan dan menetapkan kebijakan JPH; b. menetapkan norma, standar, prosedur, dan kriteria JPH; c. menerbitkan dan mencabut Sertifikat Halal dan Label Halal pada Produk; d. melakukan registrasi Sertifikat Halal pada Produk luar negeri; e. melakukan sosialisasi, edukasi, dan publikasi Produk Halal; f. melakukan akreditasi terhadap LPH; g. melakukan registrasi Auditor Halal; h. melakukan pengawasan terhadap JPH; i. melakukan pembinaan Auditor Halal; dan j. melakukan kerja sama dengan lembaga dalam dan luar negeri di bidang penyelenggaraan JPH.

Dalam melaksanakan wewenang tersebut BPJPH bekerja sama dengan kementerian dan/atau lembaga terkait; Lembaga Pemeriksa Halal; dan Majelis Ulama Indonesia. Kerja sama BPJPH dengan kementerian dan/atau lembaga terkait sebagaimana dimaksud dilakukan sesuai dengan tugas dan fungsi kementerian dan/atau lembaga terkait untuk pemeriksaan dan/atau pengujian Produk. Kerja sama BPJPH dengan MUI dilakukan dalam bentuk sertifikasi Auditor Halal; penetapan kehalalan Produk; dan akreditasi Lembaga Pemeriksa Halal. Penetapan kehalalan Produk dikeluarkan MUI dalam bentuk Keputusan Penetapan Halal Produk.

Bahan yang digunakan dalam Proses Produk Halal terdiri atas bahan baku, bahan olahan, bahan tambahan, dan bahan penolong. Bahan yang dimaksud tersebut berasal dari: a. hewan; b. tumbuhan; c. mikroba; atau d. bahan yang dihasilkan melalui proses kimiawi, proses biologi, atau proses rekayasa genetik. Bahan yang berasal dari hewan sebagaimana dimaksud pada dasarnya halal, kecuali yang diharamkan menurut syariat. 
Musyfikah Ilyas

Bahan yang berasal dari hewan yang diharamkan sebagaimana dimaksud meliputi: a. bangkai; b. darah; c. babi; dan/atau d. hewan yang disembelih tidak sesuai dengan syariat. Bahan yang berasal dari hewan yang diharamkan selain sebagaimana yang telah disebutkan diatas ditetapkan oleh Menteri berdasarkan fatwa MUI. Hewan yang digunakan sebagai bahan Produk wajib disembelih sesuai dengan syariat dan memenuhi kaidah kesejahteraan hewan serta kesehatan masyarakat veteriner.

Bahan yang berasal dari tumbuhan pada dasarnya halal, kecuali yang memabukkan dan/atau membahayakan kesehatan bagi orang yang mengkonsumsinya. Bahan yang berasal dari mikroba dan bahan yang dihasilkan melalui proses kimiawi, proses biologi, atau proses rekayasa genetik diharamkan jika proses pertumbuhan dan/atau pembuatannya tercampur, terkandung, dan/atau terkontaminasi dengan bahan yang diharamkan.

Selanjutnya mengenai Proses Produk Halal mulai dari lokasi, tempat, dan alat PPH wajib dipisahkan dengan lokasi, tempat, dan alat penyembelihan, pengolahan, penyimpanan, pengemasan, pendistribusian, penjualan, dan penyajian Produk tidak halal. Lokasi, tempat, dan alat PPH wajib dijaga kebersihan dan higienitasnya; bebas dari najis; dan bebas dari Bahan tidak halal. Pelaku Usaha yang tidak memisahkan lokasi, tempat, dan alat PPH dapat dikenai sanksi administratif berupa peringatan tertulis atau denda administratif.

Mengenai pelaku usaha berhak memperoleh: a. informasi, edukasi, dan sosialisasi mengenai sistem JPH; b. pembinaan dalam memproduksi Produk Halal; dan c. pelayanan untuk mendapatkan Sertifikat Halal secara cepat, efisien, biaya terjangkau, dan tidak diskriminatif. Pelaku Usaha yang mengajukan permohonan Sertifikat Halal wajib: a. memberikan informasi secara benar, jelas, dan jujur; b. memisahkan lokasi, tempat dan alat penyembelihan, pengolahan, penyimpanan, pengemasan, pendistribusian, penjualan, dan penyajian antara Produk Halal dan tidak halal; c. memiliki Penyelia Halal; dan d. melaporkan perubahan komposisi Bahan kepada BPJPH. Pelaku Usaha yang telah memperoleh Sertifikat Halal wajib: a. mencantumkan Label Halal terhadap Produk yang telah mendapat Sertifikat Halal; b. menjaga kehalalan Produk yang telah memperoleh Sertifikat Halal; c. memisahkan lokasi, tempat dan penyembelihan, alat pengolahan, penyimpanan, pengemasan, 
pendistribusian, penjualan, dan penyajian antara Produk Halal dan tidak halal; d. memperbarui Sertifikat Halal jika masa berlaku Sertifikat Halal berakhir; dan e. melaporkan perubahan komposisi Bahan kepada BPJPH. Pelaku Usaha yang tidak melakukan kewajiban tersebut dikenai sanksi administratif berupa peringatan tertulis; denda administratif; atau pencabutan Sertifikat Halal.

Pada tahapan selanjutnya mengenai tata cara memperoleh sertifikat halal. Permohonan Sertifikat Halal diajukan oleh Pelaku Usaha secara tertulis kepada BPJPH. Permohonan Sertifikat Halal harus dilengkapi dengan dokumen data Pelaku Usaha; nama dan jenis Produk; daftar Produk dan Bahan yang digunakan; dan proses pengolahan Produk. Selanjutnya penetapan kehalalan produk dilakukan oleh MUI. Penetapan kehalalan Produk dilakukan dalam Sidang Fatwa Halal. Sidang Fatwa Halal MUI mengikutsertakan pakar, unsur kementerian/lembaga, dan/atau instansi terkait. Sidang Fatwa Halal memutuskan kehalalan Produk paling lama 30 (tiga puluh) hari kerja sejak MUI menerima hasil pemeriksaan dan/atau pengujian Produk dari BPJPH. Keputusan Penetapan Halal Produk ditandatangani oleh MUI. Keputusan Penetapan Halal Produk disampaikan kepada BPJPH untuk menjadi dasar penerbitan Sertifikat Halal. Dalam hal Penerbitan sertifikat halal pada Sidang Fatwa Halal menetapkan halal pada Produk yang dimohonkan Pelaku Usaha, BPJPH menerbitkan Sertifikat Halal. Dalam hal Sidang Fatwa Halal menyatakan Produk tidak halal, BPJPH mengembalikan permohonan Sertifikat Halal kepada Pelaku Usaha disertai dengan alasan. Sertifikat Halal diterbitkan oleh BPJPH paling lama 7 (tujuh) hari kerja terhitung sejak keputusan kehalalan Produk diterima dari MUI. Penerbitan Sertifikat Halal wajib dipublikasikan oleh BPJPH. BPJPH menetapkan bentuk Label Halal yang berlaku nasional. Pelaku Usaha yang telah memperoleh Sertifikat Halal wajib mencantumkan Label Halal pada kemasan Produk; bagian tertentu dari Produk; dan/atau tempat tertentu pada Produk. Pencant uman Label Halal sebagaimana dimaksud dalam Pasal 38 harus mudah dilihat dan dibaca serta tidak mudah dihapus, dilepas, dan dirusak. Pelaku Usaha yang mencantumkan Label Halal tidak sesuai dengan ketentuan dikenai sanksi administratif berupa teguran lisan; peringatan tertulis; atau pencabutan Sertifikat Halal. 
Musyfikah Ilyas

BPJPH melakukan pengawasan terhadap JPH, Pengawasan JPH dilakukan terhadap LPH; masa berlaku Sertifikat Halal; kehalalan Produk; pencantuman Label Halal; pencantuman keterangan tidak halal; pemisahan lokasi, tempat dan alat penyembelihan, pengolahan, penyimpanan, pengemasan, pendistribusian, penjualan, serta penyajian antara Produk Halal dan tidak halal; keberadaan Penyelia Halal; dan/atau kegiatan lain yang berkaitan dengan JPH.

Masyarakat dapat berperan serta dalam penyelenggaraan JPH. Peran serta masyarakat dapat berupa: melakukan sosialisasi mengenai JPH; dan mengawasi Produk dan Produk Halal yang beredar. Peran serta masyarakat berupa pengawasan Produk dan Produk Halal yang beredar berbentuk pengaduan atau pelaporan ke BPJPH.

Pada saat Undang-Undang ini mulai berlaku, semua Peraturan Perundangundangan yang mengatur mengenai JPH dinyatakan masih tetap berlaku sepanjang tidak bertentangan dengan ketentuan dalam UndangUndang ini. Kewajiban bersertifikat halal bagi Produk yang beredar dan diperdagangkan di wilayah Indonesia mulai berlaku 5 (lima) tahun terhitung sejak Undang-Undang ini diundangkan.

Dari manifestasi penjabaran Undang-undang tersebut diatas dapat dipetakan sebagai berikut:

\section{Bahan Produk Halal}

Bahan yang digunakan dalam proses produk halal terdiri dari bahan baku, bahan olahan, bahan tambahan, dan bahan penolong. Bahan yang dimaksud berasal dari hewani, tumbuhan, mikroba atau bahan yang dihasilkan melaui proses kimiawi, proses biologi atau proses rekayasa genetik. Bahan yang berasal dari hewani pada dasarnya halal kecuali yang diharamkan menurut syariat Islam. Bahan yang berasal dari hewan yang diharamkan seperti bangkai, darah, babi dan atau hewan yang disembelih tidak sesuai dengan syariat. Hewan yang digunakan sebagai bahan produk wajib disembelih sesuai syariat Islam dan memenuhi kaidah kesejahteraan hewan serta kesehatan masyarakat veteriner. Bahan yang berasal dari tumbuhan pada dasarnya halal, kecuali yang memabukkan dan atau membahayakan kesehatan bagi orang yang mengkonsumsinya. Bahan dari mikroba dan bahan yang dihasilkan melalui proses kimiawi, proses biologi, atau proses rekayasa genetik diharamkan jika proses 
pertumbuhan dan atau pembuatannya tercampur, terkandung dan/ atau terkontaminasi dengan bahan yang diharamkan.

\section{Proses Produk Halal}

Lokasi tempat dan alat proses produk halal wajib dipisahkan dengan lokasi, tempat dan alat penyembelihan, pengolahan, penyimpangan, pengemasan, pendistribusian, penjualan dan penyajian produk halal. Lokasi dan tempat dan alat proses produk halal wajib untuk dijaga kebersihan dan higienitasnya, bebas dari najis dan bebas dari bahan tidak halal.

\section{Tata cara memperoleh sertifikat halal}

Pengajuan permohonan dilakukan oleh pelaku usaha dengan melengkapi dokumen data, Penetapan lembaga pemeriksa halal oleh BPJPH untuk menetapkan lembaga pemeriksa halal, pemeriksaan dan pengujian kehalalan produk, penetapan kehalalan produk dilakukan oleh MUI dalam sidang fatwa dan keputusan kehalalan produk diterima dari MUI, maka badan penyelenggara jaminan produk halal menerbitkan sertifikat pada produk halal.

\section{Labelisasi halal}

Terbitnya sertifikasi halal maka pelaku usaha wajib mencantumkan label halal pada kemasan produk, bagian tertentu dari produk dan/ atau tempat tertentu pada produk yang tentunya label yang dicantumkan yang telah ditetapkan oleh badan penyelenggara jaminan produk halal yang berlaku nasional.

Label sebagai informasi berfungsi : pertama, mengubah perilaku konsumen terhadap produk, kedua mengakomodasi preferensi konsumen serta meningkatkan keamanan pangan (food safety) dan ketiga, sebagai jaminan bahwa Negara sedang mempertimbangkan kepentingan konsumen (cunsemur interests). ${ }^{6}$ Dengan demikian, tujuan dari label adalah sebagai informasi untuk membantu konsumen mengindetifikasi produk makanan yang paling sesuai dengan pilihan mereka. Jika konsumen mengetahui identitas suatu produk dengan jelas, memungkinkan bagi konsumen untuk memilih produk yang disukai dalam konteks ini, memberikan informasi adalah upaya meningkatkan kesejahteraan dan meningkatkan kebebasan konsumen untuk

\footnotetext{
${ }^{6}$ Zulham, Hukum Perlindunan Konsumen (Cet. II; Kencana: Jakarta, 2013), h. 116
} 
Musyfikah Ilyas

menggunakan hak pilih mereka, karena konsumen membuat keputusan berdasarkan informasi yang ada pada label. Jadi label sangat membantu konsumen untuk mendapat informasi yag akurat mengenai produk tersebut bagi kemanfaatan dan kesejahteraan konsumen.

Sertifikasi dan labelisasi halal membantu konsumen untuk mengetahui sifat dan produk, sehingga memungkinkan bagi konsumen untuk memilih berbagai produk yang saling bersaing (competing products). Informasi inilah yang dibutuhkan konsumen pada produk panganan halal, dengan informasi yang simetris, konsumen dapat menentukan pilihannya untuk mengkonsumsi produk panganan halal, karena informasi yang simetris merupakan kesejahteraan (walfare) bagi konsumen, sehingga dengan sertifikasi dan dan labelisasi tercipta keadilan bagi konsumen.

\section{Sertifikasi dan labelisasi halal Perspektif Maslahat}

Sertifikasi dan labelisasi produk halal merupakan hasil pemikiran hukum Islam yang semuanya dibangun atas pertimbangan maslahat. Misi yang dibawa oleh agama Islam sendiri adalah untuk kemaslahatan manusia. Begitu pula ketentuan-ketentuan hukumnya, tidak bisa dilepaskan dari pertimbangan maslahat atau tidak. Namun demikian, apa yang disebut "kemaslahatan" dari masa ke masa selalu mengalami perubahan dan perkembangan seiring dinamika yang terjadi di tengah masyarakat. Maslahat berasal dari kata al-islah yang berarti damai dan tentram. Damai berorientasi pada fisik sedangkan tentram berorientasi pada psikis. Lawan dari maslahah adalah mafsadat dari fasada yafsudu artinya sesuatu yang merusak dan tidak baik.

Dalam perspektif Islam konsep maslahat identik dengan manfaat. Segala sesuatu yang mengandung manfaat bagi dari upaya untuk memperolehnya maupun upaya menghindarkannya dari bahaya. Maslahat adalah manfaat yang menjadi tujuan Allah swt. terhadap hambanya, dalam hal menjaga agama, jiwa, akal, keturunan dan harta benda. Sementara manfaat adalah kenikmatan atau sesuatu yang menjadi perantara pada kenikmatan dan menolak bahaya ataupun semua yang menjadi perantaranya. Manfaat merupakan suatu standar yang berhubungan dengan kebaikan dalam kehidupan manusia. Manfaat dan maslahat yang ada dalam hukum Islam yaitu manfaat yang sesuai fitrah manusia, karena Islam adalah agama yang sesuai dengan fitrah demikian pula dengan hukum-hukum yang terkait dengannya. 
Musyfikah Ilyas

Maslahat bisa dijadikan dalil, dampak maslahat dan mafsadah tidak hanya di dunia, tapi juga berdampak pada kehidupan akhirat, jadi pekerjaan yang menghasilkan sesuatu yang baik walaupun hasinya tidak secara langsung maka termasuk kategori amal saleh. Setiap pekerjaan yang diyakini akan membuahkan hasil yang baik di masa sekarang dan yang akan datang adalah termasuk maslahat. Maslahat tidak dinilai dari kenikmatan materi saja, akan tetapi sesgala sesuatu yang menjadi kebutuhan bagi tubuh, jiwa dan roh manusia. Maslahat agama menjadi dasar bagi maslahat yang lain, dan posisinya harus didahulukan. ${ }^{7}$

Maslahat diartikan sebagai manfaat atau pekerjaan yang mengandung manfaat. Menurut Imam al-Gazali maslahat adalah mengambil manfaat dan menolak kemudharatan dalam rangka memenuhi tujuan-tujuan syariat. Maslahat dikemukakan ulama ushul fikh dalam membahas metode yangdipergunakan saat melakukan istinbat yaitu menetapkan hukum berdasarkan dalil-dalil yang terdapat pada nash. ${ }^{8}$

Dalam konteks sertifikasi dan labelisasi produk halal, maka konsep maslahat sangat tepat untuk diterapkan bagi pemenuhan kebutuhan hidup manusia.

\section{Bentuk Maslahat}

Maslahat dapat dikategorikan dalam dua bentuk yaitu pertama mewujudkan manfaat, kebaikan dan kesenangan untuk manusia yang disebut جلب المنافع (membawa manfaat). Kebaikan dan kesenangan itu ada yang langsung dirasakan oleh yang melakukan saat melakukan perbuatan yang disuruh itu. Kedua menghindari umat manusia dari kerusakan dan keburukan yang disebut درع المفاسد (menolak kerusakan). Kerusakan dan keburukan itu ada yang langsung dirasakannya setelah melakukan perbuatan yang dilarang, ada juga yang pada waktu berbuat, dirasakannya sebagai sesuatu yang menyenangkan tetapi setelah itu dirasakan kerusakan dan keburukannya.

Pembagian Maslahat

1. Al-Maslahah ad-darūriyyah (ضرورية)

Kemaslahatan yang berhubungan dengan kebutuhan pokok umat manusia di dunia dan di akhirat. Yang termasuk dalam kemaslahatan ini adalah memelihara agama,

\footnotetext{
${ }^{7}$ Ika Yunia Fausia dan Abdul Kadir, Prinsip dasar Ekonomi Islam Perspektif Maqasishid alSyari'ah (Cet. 2; Jakarta: Kencana, 2015), h.111-112

${ }^{8}$ Ensiklopedia Hukum Islam Jilid IV (Cet. V; Jakarta: PT. Ichtiar Baru Van Hoeve, 2001), h. 1143
} 
memelihara jiwa, memelihara akal, memelihara keturunan dan memelihara harta, yang selanjutnya diistilahkan al-masalih al-khamzah. Misalnya untuk memelihara akal adalah faktor dalam menentukan kehidupannya, sehingga Allah swt. menjadikan akal sebagai sesuatu yang pokok. Untuk itu Allah swt. melarang meminum minuman keras, karena bisa merusak akal dan hidup manusia.

2. Al-Maslahah al Hajjiyah ( حاجية )

Maslahah al-hajjiyyah, yaitu kemaslahatan yang dibutuhkan dalam menyempurnakan kemaslahatan pokok atau mendasar sebelumnya yang berbentuk keringanan untuk mempertahankan dan memelihara kebutuhan dasar manusia. Misalnya dalam muamalah dibolehkan bekerjasama dalam pertanian muzārāāh.

3. Al-Maslahah Takhsiniyah (تحسينية)

Kemaslahatan yang sifatnya pelengkap berupa keleluasaan yang dapat melengkapi kemaslahatan sebelumnya. Misalnya dianjurkan makan makanan yang bergizi. ${ }^{9}$

Kebutuhan konsumen terhadap sertifikasi dan labelisasi produk halal dikategorikan sebagai maslahat dharuriyyah karena terkait dengan kemaslahatan yang keberadaanya sangat dibutuhkan oleh kehidupan manusia, sebagai pemenuhan kebutuhan hajat hidup orang banyak. Sertifikasi dan labelisasi produk halal sebagai maslahat daruriyyah tentu saja dilakukan secara bertahap karena sangat sulit dilakukan sertifikasi dan labelisasi produk halal secara bersamaan oleh karenanya diperlukan pemetaan produk mana yang diprioritaskan, sehubungan dengan itu maka dibutuhkan peraturan pemerintah lebih lanjut.

Dengan adanya sertifikasi dan labelisasi halal membantu masyarakat memilih dan menginformasikan mengenai produk halal sebagai kebutuhan dalam rangka memenuhi kemaslahatan yakni menjaga dan memelihara agama, jiwa, akal, keturunan, dan harta.

Sertifikasi dan labelisasi produk halal tentu sangat dianjurkan karena terkait mendatangkan kebaikan dan manfaat dan tentunya menjauhkan dari kemudaratan, sebagaimana kaidah ushul sebagai berikut:

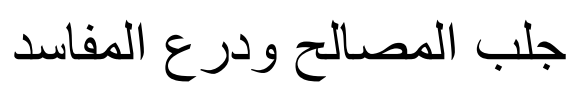

\footnotetext{
${ }^{9}$ Amir Syarifuddin, Ushul Fiqh, Jilid 2 (Cet IV; Jakarta: Kencana, 2008), h. 207-215.
} 
"Meraih kemaslahatan dan menolak kemafsadatan".

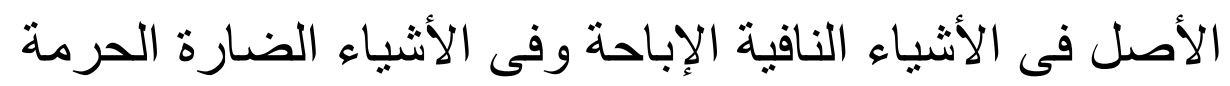

"Hukum asal sesuatu yang bermanfaat adalah boleh dan hukum asal sesuatu yang berbahaya adalah haram".

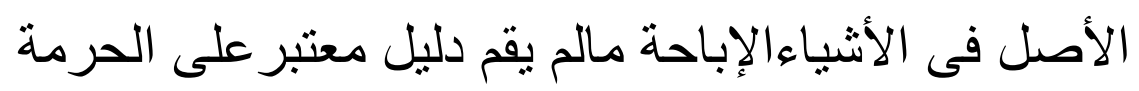

"Hukum asal mengenai sesuatu adalah boleh selama tidak ada dalil muktabar yang mengharamkannya".

Seluruh syariat adalah maslahat, baik dengan cara menolak mafsadat atau dengan meraih maslahat, pekerjaan manusia ada yang membawa kepada maslahat, adapula yang menyebabkan kepada mafsadat. Baik maslahat dan mafsadat ada yang untuk kepentingan dunia dan adapula yang untuk kepentingan akhirat, dan ada juga yang untuk kepentingan dunia sekaligus akhirat. Seluruh yang maslahat diperintahkan oleh syariat dan seluruh yang mafsadat dilarang oleh syariat. Setiap kemaslahatan memiliki tingkatan tertentu tentang kebaikan dan manfaatnya serta pahalanya, dan setiap kemafsadatan juga memiliki tingkatan dalam keburukan dan kemudharatannya.

Kemaslahatan dari sisi syariah bisa dibagi tiga, ada yang wajib dilaksanakan, ada yang sunnah dilaksanakan dan ada yang mubah dilaksanakan dan kemafsadatan ada yang haram dilakukan dan ada yang makruh dilakukannya. ${ }^{10}$

Dengan demikian kemaslahatan terhadap sertifikasi dan labelisasi halal adalah kemaslahatan dunia dan akhirat, dan dianjurkan untuk dilakukan karena terkait dengan perintah kewajiban untuk mengkonsumsi produk halal, dan tindakan preventif di era sekarang untuk mengetahui produk halal atau produk tidak halal maka tidak ada jalan lain selain pelaku usaha melakukan sertifikasi produknya dan mencantumkan labelisasi produk halal yang tentunya memudahkan masyarakat untuk memenuhi hajatnya.

Dalam Q.S. al-A'raf (7): 31

${ }^{10}$ Izzuddin bin Abd al-Salam, Qawaid al-Ahkam fi Mashalih al-Anam, Juz I (Dar al-Jail, 1980), h. 11. 


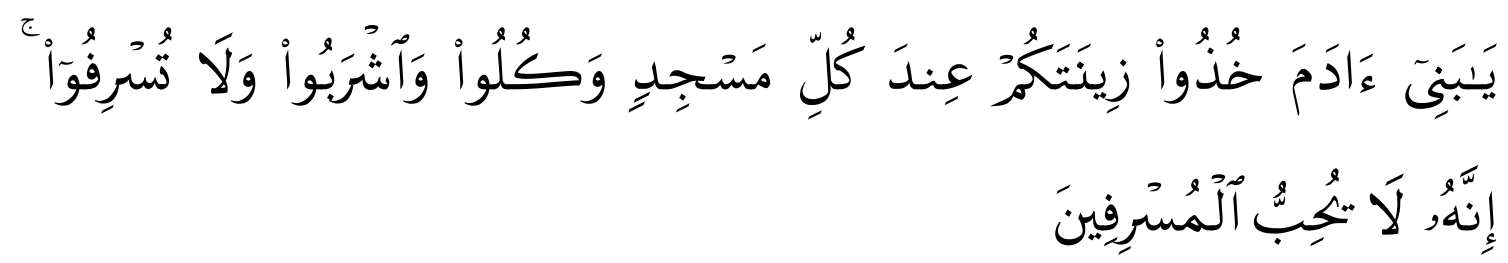

Terjemahan : Hai anak Adam, pakailah pakaianmu yang indah di Setiap (memasuki) mesjid, Makan dan minumlah, dan janganlah berlebih-lebihan. Sesungguhnya Allah tidak menyukai orang-orang yang berlebih-lebihan.

Hadis yang berkenaan dengan kehalalan dan keharaman sesuatu yang di konsumsi

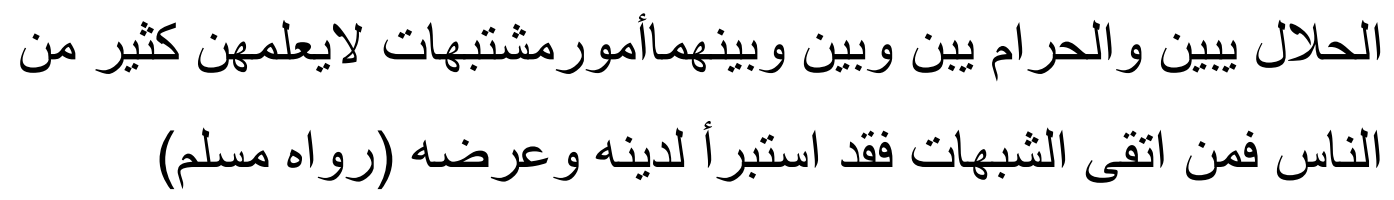

Artinya :

"Yang halal itu sudah jelas dan yang haram pun sudah jelas; dan di antara keduanya ada hal-hal yang mutasyabihat (syubhat, samar-samar, tidak jelas halal haramnya), kebanyakan manusia tidak mengetahui hukumnya. Barang siapa hati-hati dari perkara syubhat, sungguh ia telah menyelamatkan agama dan harga dirinya”.

Banyaknya produk yang beredar tidak jelas status hukumnya, halal atau haram bahkan terkadang syubhat. Dengan demikian mengkonsumsi dan memanfaatkan dan menggunakan produk halal dianjurkan yang sudah tersertifikasi dan memiliki labelisasi halal agar terhindar dari produk tidak halal yang berakibat keraguan pada masyarakat sebagai konsumen.

Maslahat sertifikasi dan labelisasi produk halal antara lain:

\section{Perlindungan terhadap ummat Islam dalam menjalankan ajarannya}

Banyaknya kasus yang muncul yang sangat menyakiti umat Muslim di Indonesia yang pada akhirnya akan menimbulkan kerugian besar bagi konsumen dan dunia usaha, yaitu : kasus bakso yang mengandung daging babi di Bandung (1984) kasus makanan yang mengandung bahan daging babi (1988) ${ }^{11}$ dan kasus vaksin

${ }^{11}$ Ma'ruf Amin, "Fatwa Halal Melindungi Umat dari Kerugian yan Lebih Besar" Jurnal Halal, No. 103 Th. XVI Tahun 2013, Jakarta: LPPOM MUI, h. 20. 
meningitis jemaah haji yang mengandung enzim babi (2009) $)^{12}$ menyikapi hal ini tentunya sangat merugikan umat Islam. Meskipun sertifikasi dan labelisasi produk halal menunjukkan perlindungan terhadap umat muslim untuk menjalankan ajarannya, namun sekaligus umat lainnya karena semua membutuhkan produk yang halal lagi baik untuk kelangsungan hidupnya, karena halal dan tayyib tentu mendatangkan kebaikan dan kemaslahatan, implementasi kaidah maslahat, seraya mengurangi kemungkinan terjadinya mudharat atau bahkan maksiat yang dilarang.

\section{Memberikan keadilan}

Regulasi undang-undang nomor 33 tahun 2014 tentang jaminan produk halal telah ditetapkan, namun masih saja sertifikasi dan labelisasi produk halal dilakukan secara sukarela, sehingga keadilan yang diinginkan oleh ummat Islam masih sulit didapatkan karena muncul keragua-raguan, misalnya tempat-tempat umum yang banyak dijajakan makanan namun sering kali menjadi tanda tanya apakah produknya halal atau produknya tidak halal. Oleh karena itu penyelenggaraan jaminan produk halal berasaskan perlindungan, keadilan, kepastian hukum, akuntabilitas dan transparansi, efektivitas dan efesiensi serta profesionalitas. ${ }^{13}$

\section{Kesehatan}

Jaminan produk halal berarti ada upaya menuju terciptanya kesehatan jiwa masyarakat yang seoptimal mungkin baik dari segi intelektual emosional, dan psikososial. Rasa aman dan ketenangan mengkonsumsi produk halal akan membawa seseorang pada kenyamanan jiwa yang berimbas pada sikap dan tindakan masyarakat dimana mereka tinggal. Pola mengkonsumsi makanan tidak halal akan menimbulkan efek kejiwaan mental yang mendalam. Maka tidaklah berlebihan bila banyak yang mengindikasikan bahwa keberingasan, perkelahian dan tidak bersahabat dari masyarakat tidak lepas dari pola mengkonsumsi produk tidak halal .

\footnotetext{
${ }^{12}$ Fokus, "Mendamba Vaksin Menginitis Halal", Jurnal Halal No. 78 Th. XII Tahun 2009, Jakarta : LPPOM MUI, h. 8.

${ }^{13}$ Pasal 2 Undang-Undang Nomor 33 Tahun 2014 tentang Jamina Produk Halal.
} 
Musyfikah Ilyas

Pada kenyataannya memang pihak-pihak yang kerap dirugikan dalam ketidakjujuran produsen terhadap informasi isi bahan produk adalah bayi dan wanita hamil. Padahal jelas bahwa kedua faktor itulah yang akan menjadi tulang punggung Negara Indonesia ke depan. Dengan demikian semakin memperkuat sinyalemen permasalahan dalam produk halal dapat mengancam keutuhan Negara bukanlah isapan jempol belaka. ${ }^{14}$ Beberapa penyakit yang ditimbulkan karena menkonsumsi produk tidak halal misalnya mengkonsumsi daging babi yang berdampak pada kesehatan, menimbulkan penyakit bagi manusia karena mengandung kuman dan parasite ${ }^{15}$.

\section{Kepastian Hukum sebagai Warga Negara}

Legalisasi Undang-undang nomor 33 Tahun 2014 tentang jaminan produk halal akan memberikan kepastian hukum guna memberikan jaminan atas kenyamanan, keamanan, keselamatan dalam penggunaan dan memanfaatkan produk halal. Serta untuk mencegah penipuan, untuk membantu konsumen memaksimalkan pilihan mereka terhadap produk untuk kemanfaatan atau kesejahteraan mereka. Agar konsumen bertindak sesuai dengan kepentingan terbaik mereka dan berdasarkan pilihan mereka.

Pergeseran paradigma telah terjadi model sukarela (voluntary) ini, jika masih dipertahankan, banyak pihak menjadi korban pelanggaran norma pelaku usaha, terutama konsumen. Banyaknya bukti menunjukkan pelaku usaha cenderung melakukan pelanggaran, utamanya dalam menggunakan bahan campuran makanan (misalnya bahan pengawet, pewarna, ramuan dan penyedap rasa). Hal ini merupakan pengingkaran pelaku usaha terhadap norma hukum tentang produk halal yang ada meskipun masih bersifat parsial.

Paradigma lain adalah sertifikasi halal bersifat wajib (mandatory). Undangundang jaminan produk halal melakukan perbuatan hukum ijtihadi dengan cara membuat konstruksi hukum bahwa sertifikasi produk itu bersifat wajib.

\footnotetext{
${ }^{14}$ Departemen Agama, Pedoman Strategi Kampanye Sosial Produk Halal, Jakarta: Direktorat Jenderal Bimbingan Masyarakat Islam dan Penyelengaraan Haji, 2003. h.51-52.

${ }^{15}$ Ahsin W. Al Hafidz, Fikih Kesehatan (Cet. I; Jakarta: Amzah, 2007), h.192. dan Thobieb alAsyhar, Bahaya Makanan Haram Bagi Kesehatan Jasmani dan Kesucian Rohani (Cet. I; Jakarta: AlMawardi Prima, 2003), h. 186.
} 
Konsekwensinya bahwa hukum wajib bersetifikat halal harus memiliki landasan baru. Sifat wajib bersertifikat halal berarti undang-undang jaminan produk halal telah terlepas dari asas dan doktrin moral yang menjadi penyangganya asas suka rela.

Untuk maksud ini, undang-undang jaminan produk halal telah meletakkan kaidah baru sebagai dasar baru bagi hukum wajibnya sertifikasi produk. Namun demikian sebelum kewajiban bersertifikat diberlakukan, maka jenis-jenis produk yang wajib bersertifikat halal diatur secara bertahap harus ditetapkan peraturan pemerintah sebagai acuan dalam langkah selanjutnya. Sertifikasi produk halal dan labelisasi produk halal dilakukan untuk memberikan kepastian status kehalalan, sehingga dapat menenteramkan batin konsumen dalam mengkonsumsinya. Kesinambungan proses produksi halal dijamin oleh produsen dengan cara menerapkan sistem jaminan halal.

\section{PENUTUP}

\section{Kesimpulan:}

1. Sertifikasi dan labelisasi produk halal perspektif maslahat merupakan tujuan syariat dalam melindungi umat Islam dalam memenuhi hajat dan memberikan kepastian hukum terhadap kehalalan suatu produk yang dibuktikan dengan sertifikasi dan labelisasi produk halal.

2. Sertifikasi dan labelisasi produk halal dikategorikan sebagai maslahah dharuriyah yang tentunya kewajiban sertifikasi dan labelisasi halal dilakukan secara bertahap karena keberadaanya sangat dibutuhkan oleh kehidupan manusia. untuk kemaslahatan dalam memenuhi kebutuhan dalam rangka memelihara agama, jiwa, akal, keturunan, dan harta.

\section{Implikasi}

Sertifikasi dan labelisasi produk halal sudah sangat mendesak untuk dilakukan karena kesemuanya itu dapat memberikan jaminan kepada konsumen, dan keberadan maslahat dalam sertifikasi dan labelisasi produk halal dapat menyelesaikan persoalan umat tentang produk halal dan menambah wawasan khazanah keilmuan perspektif hukum Islam. 


\section{Daftar Pustaka}

Ahsin W. Al Hafidz, Fikih Kesehatan. Cet. I; Jakarta: Amzah, 2007.

Amir Syarifuddin, Ushul Fiqh, Jilid 2. Cet IV; Jakarta: Kencana, 2008.

Departemen Agama, Pedoman Labelisasi Halal, Jakarta: Direktorat Jenderal Bimbingan Masyarakat Islam dan Penyelengaraan Haji, 2003.

Departemen Agama, Al-Qur'an dan Tafsirnya, Jilid 3. Cet.III; Jakarta: Lembaga Percetakan al-Qur'an Departemen Agama, 2009.

Departemen Agama, Himpunan Fatwa Majlis Ulama Indonesia. Jakarta: Direktorat Jenderal Bimbingan Masyarakat Islam dan Penyelenggaraan Haji, 2003.

Departemen Agama, Pedoman Strategi Kampanye Sosial Produk Halal, Jakarta:

Direktorat Jenderal Bimbingan Masyarakat Islam dan Penyelengaraan Haji, 2003.

Ensiklopedia Hukum Islam Jilid IV. Cet. V; Jakarta: PT. Ichtiar Baru Van Hoeve, 2001.

Fokus, "Mendamba Vaksin Menginitis Halal", Jurnal Halal No. 78 Th. XII Tahun 2009, Jakarta: LPPOM MUI.

Ika Yunia Fausia dan Abdul Kadir, Prinsip dasar Ekonomi Islam Perspektif Maqasishid al-Syari'ah. Cet. 2; Jakarta: Kencana, 2015.

Izzuddin bin Abd al-Salam, Qawaid al-Ahkam fi Mashalih al-Anam, Juz I (Dar al-Jail, 1980), h. 11.

Ma'ruf Amin, "Fatwa Halal Melindungi Umat dari Kerugian yan Lebih Besar" Jurnal Halal, No. 103 Th. XVI Tahun 2013, Jakarta: LPPOM MUI.

M. Sadar, Moh.Taufik Makaroi, Habloel Mawardi, Hukum Perlindungan Konsumen di Indonesia. Cet.I; Jakarta: Akademia, 2012.

Thobieb al-Asyhar, Bahaya Makanan Haram Bagi Kesehatan Jasmani dan Kesucian Rohani. Cet. I; Jakarta: Al-Mawardi Prima, 2003.

Undang-undang No. 33 Tahun 2014 tentang Jaminan Produk Halal.

Zulham, Hukum Perlindunan Konsumen. Cet. II; Kencana: Jakarta, 2013. 